\title{
Klasyfikacja lodu jako podstawa do określenia granic i powierzchni Antarktydy
}

\author{
Ice classification as a basis for determining \\ the borders and area of Antarctica
}

\author{
WOJCIECH DOBIŃSKI \\ Wydział Nauk o Ziemi, Uniwersytet Śląski, \\ 41-200 Sosnowiec, ul. Będzińska 60; wojciech.dobinski@us.edu.pl
}

\begin{abstract}
Zarys treści. W artykule przedstawiono nieścisłości związane z klasyfikacją lodu, których skutkiem są poważne trudności w jednoznacznym określeniu granic i powierzchni Antarktydy, a tym samym w traktowaniu Antarktydy jako kontynentu. Zmiana klasyfikacji lodu i przeniesienie go z hydrosfery do litosfery pozwoliłaby na ujednolicenie i uporządkowanie badań lodu we wszystkich subdyscyplinach z zakresu nauk o Ziemi.
\end{abstract}

Słowa kluczowe: Antarktyda, granice, lód, kontynent.

\section{Wstęp}

Antarktyda powszechnie traktowana jest jako kontynent. Opinia ta nie budzi wątpliwości, dopóki nie będziemy wnikać w kryteria takiego twierdzenia. Kontynentem nazywamy ciągły ląd (łac. continuum), stąd jego nazwa. O włączeniu lądu do zbioru kontynentów decyduje także wielkość tego fragmentu litosfery. Antarktyda z pewnością spełnia to kryterium. Jednak niemal cała jej powierzchnia pokryta jest lodem, który powszechnie klasyfikowany jest jako składnik hydrosfery. To lód decyduje o rozmiarach jej powierzchni, wysokości, kształcie i granicach. W pracy przedstawiono poglądy na temat powierzchni i różnych granic Antarktydy oraz trudności w ich wytyczaniu, a także w definiowaniu lodu i zasięgu wieloletniej zmarzliny na Antarktydzie. Bez ich jednoznacznego rozstrzygnięcia nadal będą wątpliwości, czy należy traktować Antarktydę jako kontynent. Rozstrzygnięcie to jest ważne, ponieważ dotyczy znacznego obszaru niemal $14 \mathrm{mln} \mathrm{km}^{2}$ powierzchni to jest prawie 10\% powierzchni lądów. 


\section{Definicja granicy}

Każda dyscyplina naukowa wymaga porządku i wewnętrznej spójności, która w znacznej mierze bierze się z klasyfikacji opisywanych zagadnień i ich hierarchizacji. Aby ten naukowy porządek był możliwy, konieczne jest w opisie środowiska geograficznego określenie lub ustanowienie granic. Pojęcie, definicja granicy jest oczywiście decydujące w rozwinięciu zamierzonego tematu. Pojęcie granicy w badaniach geograficznych zostało wyczerpująco scharakteryzowane w artykule J. Bańskiego (2010), który wykorzystano w tej pracy jako podstawowe źródło do krótkiej jej charakterystyki. Granica liniowa, zwłaszcza w postaci prostoliniowej spotykana jest w środowisku naturalnym niezwykle rzadko. Granice liniowe to głównie te, które wytyczone są w sposób sztuczny, np. administracyjnie. Nie zawsze są one oznaczane w sposób materialny (np. granice województw, powiatów), lecz czasem ich materialny wyraz jest wyjątkowo spektakularny, jak w postaci chińskiego muru, czy granicy pomiędzy Niemiecką Republiką Federalną a Niemiecką Republiką Demokratyczną wyznaczoną po II wojnie światowej. Granice te można też określić jako sztuczne, wytyczone dowolnie, czy umownie przez człowieka, w przeciwieństwie do granic naturalnych, czyli tych, które wyznaczone są przez przyrodę. Granice naturalne zwykle są granicami strefowymi. Osobną kwestią jest obraz granicy zidentyfikowanej lub wyznaczonej na mapie. Najbardziej chyba dla wszystkich oczywistą granicą jest granica ląd-morze, ale i tu wystarczy choćby chwilowa jej obserwacja, by zauważyć jej zmienność nawet podczas niewielkiego falowania.

Granica nie jest wyłącznie wytworem ludzkiego umysłu, lecz realnie istniejącą rzeczywistością. Jej dostrzeżenie wynika z poznawczych zdolności ludzkiego umysłu, czasami uzbrojonego w metodykę badawczą (pomiar), który dostrzegając - rozróżnia, rozróżniając - nazywa, nazywając - klasyfikuje i w ten sposób gromadzi wiedzę pewną i uporządkowaną. W geografii - uporządkowaną również przestrzennie. Zrozumienie istoty granicy Antarktydy, tego co ją konstytuuje, pozwala na określenie jej powierzchni i zdecydowanie o powodach włączenia jej do zbioru kontynentów.

\section{Granica i powierzchnia Antarktydy}

Geneza zagadnienia zawartego w tytule tego rozdziału może być interesująca, ponieważ pokazuje jego istotny, szerszy kontekst. Wyrasta ono z problematyki dotyczącej zasięgu występowania wieloletniej zmarzliny na Antarktydzie. Mimo dysponowania wydajnymi i precyzyjnymi metodami pomiarowymi we współczesnych badaniach Ziemi, podawane informacje na temat powierzchni objętej występowaniem permafrostu są ogromnie rozbieżne. Ze względu na ostry zimny klimat panuje powszechna zgoda odnośnie do tego, że cały nie 
przykryty lądolodem obszar lądowy objęty jest ciągłym permafrostem. J. Bockheim i K. Hall (2002) określają wielkość tego obszaru na 0,055·10 ${ }^{6} \mathrm{~km}^{2}$. I. Campbell i G. Claridge (2009) podają wielkość 0,049·10 ${ }^{6} \mathrm{~km}^{2}$, M. Guglielmin

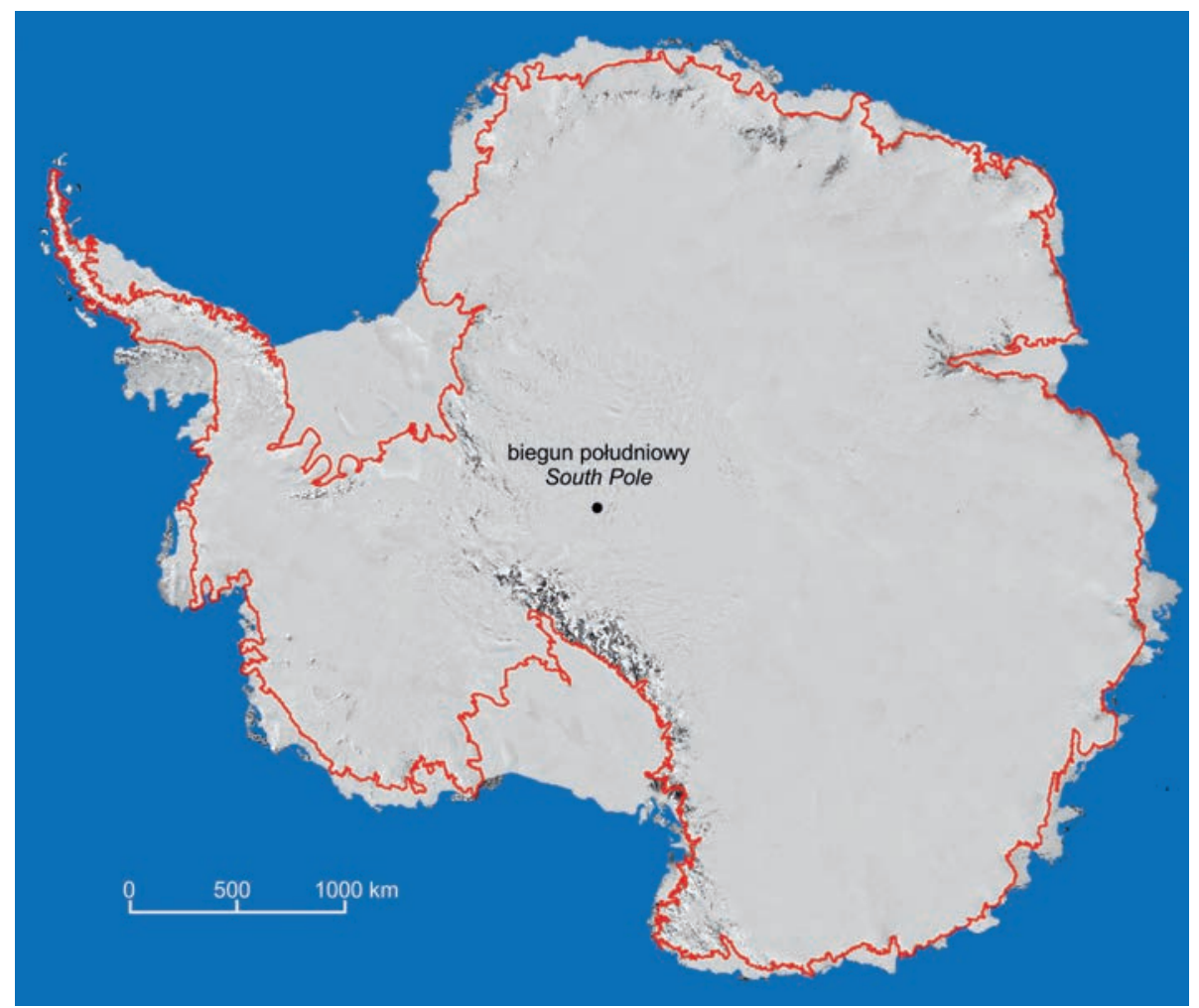

Ryc. 1. Granice maksymalnego zasięgu kontynentu wraz z przymarzniętym trwale lodem morskim tzw. fast-ice. Linią czerwoną zaznaczono zasięg tzw. grounding line,

tj. granicy, do której lodowce i lądolody zanurzone w morzu wsparte są o dno - nie unoszą się na wodzie. Obraz pozyskano dzięki uprzejmości NASA. http://www.nasa.gov/images/content/470723main_antarcticafull.jpg z niewielkimi zmianami.

Limits to the maximum extent of the continent with its so-called "fast-ice". Denoted in red is the so-called grounding line, i.e. the boundary up to which glaciers and ice sheets submerged in the sea rest on the bottom (i.e. do not float on the water).

We are very grateful to NASA for making available the image at http://www.nasa.gov/images/content/470723main_antarcticafull.jpg (as here amended slightly).

(2012) dla powierzchni niezlodowaconej podaje 0,0498·10 $\mathrm{km}^{2}$, J. Bockheim (1997) powierzchnię terenu objętego permafrostem na Antarktydzie określa na $0,28 \cdot 10^{6} \mathrm{~km}^{2}$. Z drugiej strony istnieją skrajnie odmienne opinie, np. H.M. French 
(2007) podaje, że cała Antarktyda - czyli $13,5 \cdot 10^{6} \mathrm{~km}^{2}$ - jest objęta permafrostem. Autorzy z reguły opierają się na cytowanej literaturze. Ta ogromna rozbieżność nie wzbudza kontrowersji i nie jest w środowisku naukowym dyskutowana. Moim zdaniem związana jest ona z trzema różnymi zajmowanymi przez naukowców stanowiskami:

a) nieprecyzyjnym określeniem terminu „wieloletnia zmarzlina” (permafrost), który stosowany bywa najczęściej do klasycznie rozumianej litosfery, to jest skał „nielodowych”, z apriorycznym wyłączeniem lądolodu antarktycznego jako części przemarzniętej litosfery;

b) ograniczaniem występowania permafrostu wyłącznie do podłoża lądolodu Antarktydy. Ponieważ jednak w znacznej jego części lód styka się z nim pozostając $\mathrm{w}$ temperaturze punktu topnienia pod ciśnieniem (ang. pressure melting point), na styku podłoża z lądolodem znajduje się woda i jest ono nieprzemarznięte. Jest to zgodne z obiegową opinią, że w przypadku tzw. „ciepłych" (ang. temperate) lodowców podłoże ich nie jest objęte permafrostem, ponieważ powszechnie za permafrost uważa się grunt stale zamarznięty;

c) pomijaniem stanu kriotycznego (cryotic state) jako synonimu permafrostu. Punkt topnienia pod ciśnieniem znajduje się zawsze w temperaturze niższej od $0^{\circ} \mathrm{C}$. Zgodnie zaś z definicją, wieloletnią zmarzliną nazywamy grunt lub skałę znajdującą się $\mathrm{w}$ temperaturze równej lub niższej od $0^{\circ} \mathrm{C}$ przez co najmniej dwa lata (Everdingen, 1998). Kryterium decydującym nie jest tu przemiana fazowa (zamarznięcie) lecz stan termiczny. Niezamarznięty grunt pozostający stale $\mathrm{w}$ temperaturze równej lub niższej od $0^{\circ} \mathrm{C}$ nazywany jest gruntem kriotycznym (cryotic ground) i jest synonimem permafrostu.

Powyższe kryteria decydują o tym, gdzie przeprowadza się granicę pomiędzy obszarem objętym i nieobjętym permafrostem, co w konsekwencji prowadzi do określenia zasięgu jego występowania.

Często jest też tak, że autorzy stojący na stanowisku, iż wieloletnią zmarzliną objęta może być jedynie litosfera, wykluczają z permafrostu lodowce i lądolody, powszechnie zaliczane są do hydrosfery. Pomimo podjętych starań nie udało mi się znaleźć pracy, w której przedstawiono by argumenty przemawiające za włączeniem lodu do hydrosfery. Z drugiej strony jasne jest i oczywiste - zwłaszcza dla geologów czy petrografów - że lód należy do zbioru minerałów. Tak klasyfikowany jest obecnie przez International Mineralogical Association (por.: http://rruff.info/ima/; Hall i Wood, 1985 i inne referencje tam zawarte). Lód jest wliczony do zbioru minerałów także w polskim podręczniku mineralogii (Bolewski i Manecki, 1993). Nagromadzenie jednego minerału tworzy monomineralną skałę, a zatem lodowiec jako nagromadzenie takiej skały należy przypisać do litosfery. Przyjęcie drugiego założenia daje wystarczające podstawy do wyróżnienia wieloletniej zmarzliny także w obrębie każdego lodowca i lądolodu. Takie stanowisko zajmował już L.A. Washburn (1973); szerzej zagadnienie to rozwinięto w innym miejscu (Dobiński, 2011, 2012). Niejasność w klasyfika- 
cji lodu, to jest czy należy on do litosfery, czy do hydrosfery (Dobiński, 2006), jest podstawowym powodem zamieszania, którego jednym z efektów jest właśnie trudność w określeniu granic Antarktydy. Zagadnienie to jest istotne z naukowego punktu widzenia, bez jasnego określenia stanowiska nie ma bowiem nawet pewności, czym jest przedmiot badań: czym jest Antarktyda? Jakie są przesłanki do uznania jej za kontynent, lub im przeciwne?

\section{Granica Antarktydy}

- Granicę Antarktydy może wyznaczać granica skalnego podłoża lądolodu wystająca ponad powierzchnię wody. Byłaby to granica analogiczna do granic pozostałych kontynentów. Jej określenie jest jednak bardzo trudne, ponieważ jak wyżej wykazano większa jej część przykryta jest lądolodem, więc bez szczegółowych badań relacji lód/podłoże nie jest możliwe jej określenie także w strefie przybrzeżnej. Pomocą może być wzmiankowany dalej model Bedmap 2.

- Granicę kontynentu antarktycznego może stanowić tzw. grounding line, czyli linia, do której spełzający lądolód w całości wspiera się o dno, i żadna jego część nie jest wsparta wodą - pływająca.

- Granicę kontynentu stanowić może także granica lądu wraz z barierą lodową lodowców spełzających do morza, unoszących się na wodzie, w szczególności lodowców szelfowych. W ten sposób Antarktyda prezentowana jest chyba najczęściej.

- Granicę Antarktydy określa się również poprzez zasięg tzw. fast ice, to jest wieloletniego lodu morskiego przymarzniętego do lądu lub lodowców szelfowych i tym samym pozostającego w bezruchu (Summerhayes, 2009; Convey i inni, 2009).

W zależności od przyjętego kryterium zmienia się kształt i zasięg brzegów kontynentu antarktycznego. W skrajnym przypadku ich zmienność może nawet mieć charakter sezonowy. Określenie granicy kontynentu polegać musi na wybraniu jednego z wymienionych wyżej kryteriów. Jeżeli zadaniem nauki jest dostarczenie wiedzy pewnej, konieczne staje się opowiedzenie za jedną z tych możliwości. Rozwiązanie tego problemu proponuję poniżej.

\section{Powierzchnia Antarktydy}

Określenie granic warunkuje określenie powierzchni Antarktydy, jest więc ona zmienna w takim samym stopniu jak jej granice. Spektakularnym osiągnięciem ostatnich lat jest precyzyjne określenie powierzchni podłoża lądolodu Antarktycznego w ramach projektu BEDMAP 2 (Fretwell i inni, 2013). Z przedstawionych badań wynika, że $5,5 \cdot 10^{6} \mathrm{~km}^{2}$ (44,7\%) tej powierzchni znajduje się poniżej poziomu morza. Jeżeli klasyfikujemy lód jako składnik hydrosfery, nie możemy określić powierzchni Antarktydy inaczej jak tylko na 
podstawie przedstawionego wyżej wyniku. Drugorzędne znaczenie ma tu fakt, czy hydrosfera ma postać ciała stałego czy cieczy. Owszem, jest to problem, który należałoby pilnie przedyskutować. Na dodatek ukształtowanie terenu jasno pokazuje, że Antarktyda bez pokrywy lodowej stanowi archipelag wysp podobnych - także genetycznie - do archipelagu wysp północnej Kanady. Sytuacja staje się diametralnie inna, gdy uznamy pokrywę lodową za składnik litosfery i wliczymy ją do powierzchni lądu. To daje solidne podstawy do uznania Antarktydy za kontynent i zmienia jej powierzchnię, która w zależności od przyjętego kryterium granicy może liczyć $13,5-14 \cdot 10^{6} \mathrm{~km}^{2}$.

\section{Antarktyda: granica i powierzchnia - specyfika koniecznej argumentacji}

Ustalenie jakie są powierzchnia i granice Antarktydy, a w konsekwencji udowodnienie, że jest ona kontynentem, wymaga ujęcia problemu w nieco szerszy kontekst. Przede wszystkim jednak rozstrzygnąć należy główny, trudny i rzadko podejmowany problem dotyczący klasyfikacji lodu jako składnika litosfery. Wiąże się on z ciężarem właściwym lodu, który powoduje, że unosi się on na wodzie. Ta jego właściwość powoduje, że sklasyfikowanie go jako elementu litosfery jest trudne do przyjęcia pod względem mentalnym. Jest przecież oczywiste, że hydrosfera - czy w postaci cieczy czy ciała stałego (pomijając dziwaczność takiej klasyfikacji) - znajduje się na litosferze. Wyobraźnia podpowiada, że inne, odwrotne rozwiązanie byłoby sprzeczne z tą logiką.

Argumenty przeciw takiemu stanowisku są co najmniej dwa. Pierwszy to ten, że lód jako skała unosząca się na wodzie nie jest w środowisku ziemskim wyjątkiem. Inną taką skałą występującą dosyć powszechnie na Ziemi jest pumeks. Podwodne erupcje wulkaniczne dosyć często prowadzą do powstania niejednokrotnie olbrzymich pokryw pumeksu unoszących się na wodzie (Bryan i inni, 2004). Ta ich właściwość nie wzbudza kontrowersji, w przeciwieństwie do lodu. Drugi argument pochodzi z zastosowania nauk o Ziemi w badaniach innych ciał niebieskich. Zwykle stosuje się tu klasyczną analogię - porównywanie rzeczywistości spotykanej na innych ciałach niebieskich z tą istniejącą na Ziemi, która w sposób oczywisty stanowić ma punkt odniesienia. Współcześnie bowiem powszechnym, a nawet w pewien sposób modnym kierunkiem badań jest poszukiwanie w Kosmosie analogii do warunków ziemskich. Poszukuje się zatem życia w Kosmosie, wody na innych planetach, a nawet innych, podobnych do Ziemi planet. Przy czym, chociaż każdy badacz Ziemi i Kosmosu ma świadomość wyjątkowości Ziemi we wszechświecie, wbrew logice traktuje ją, i warunki na niej panujące, jako punkt odniesienia, który wyznacza standardy w dostrzeganych na innych ciałach niebieskich analogiach. Owszem, możemy, a nawet poniekąd - musimy opisywać nowo poznawane planety według tej już poznanej - Ziemi. Do nie- 
dawna wręcz nie znaliśmy innych planet czy księżyców. Jednak obecnie już tak nie jest. Zgromadzona wiedza o Układzie Słonecznym, a także o innych galaktykach i całym Kosmosie może i powinna wywrzeć swe piętno na poznaniu i w szczególności zrozumieniu Ziemi. To spostrzeżenie skłoniło mnie do tego, aby tę zasadę analogii odwrócić: „To nie Ziemia powinna stanowić punkt odniesienia w analogicznych badaniach struktur geologicznych innych ciał niebieskich, ponieważ posiada unikalny status w kosmosie pod tym względem. To Kosmos i znajdujące się w nim ciała niebieskie stanowić powinny obszar referencyjny dla właściwego zrozumienia struktury geologicznej Ziemi” (Dobiński, 2012, s. 624).

W istocie jest to jedynie modyfikacja zasady powszechnie znanej jako zasada aktualizmu: że "teraźniejszość jest kluczem do przeszłości”, którą odnosi się w najogólniejszym ujęciu do czasu geologicznego. Modyfikacja polega natomiast na przystosowaniu jej do przestrzeni, i to w szerokim zakresie. W szczególności pozwala ona na ujednolicenie roli lodu jako składnika litosfery Ziemi i innych ciał niebieskich, pozwalając jednocześnie postrzegać go w jednolitym kontekście, a także na zastosowanie poprawnej, logicznej analogii. Nie jest powszechnie dostrzegane również to, że nie tylko astronomowie badają inne planety, księżyce, komety czy asteroidy. Nie przez astronomów opisywana jest powierzchnia innych ciał niebieskich. Ich budowa geologiczna (chociaż przedrostek „geo-” w tym złożeniu nabiera innego znaczenia) oraz szereg innych składników powszechnie klasyfikowanych w naukach o Ziemi (hydrochemii, petrografii, geofizyce itd.) badana jest przez specjalistów z tych dziedzin: geologów, geofizyków, geomorfologów, petrografów i innych. Opierają się one na zasadzie analogii, porównania środowiska ziemskiego ze znajdowanym na innych ciałach niebieskich. Wyniki tych badań obejmują w pewnym sensie zakres „nauk o Ziemi” i nie powinny pozostać bez wpływu na postrzeganie środowiska naturalnego naszej planety. Dotyczy to w szczególnym stopniu lodu.

Lód znajdowany jest bowiem dosyć powszechnie w kosmosie. Na Marsie w okolicach okołobiegunowych znajdują się czapy lodowe przypominające zlodowacenie Ziemi i jego zlodowacenie nie jest kwestionowane (Forget i inni, 2006; Head i inni, 2005). Znacznie większe nagromadzenie lodu widoczne jest na niektórych księżycach Jowisza (np. Ganimedes, Kallisto, Europa) czy Saturna: Enceladus, Tytan, Japet. Szereg z nich lód pokrywa całkowicie, tworząc ich powierzchnię nazywaną kriolitosferą, której grubość może przekraczać $100 \mathrm{~km}$. Pod tą skorupą znajduje się najczęściej wodny ocean, o głębokości (grubości) do kilkuset kilometrów (Mc Kinnon, 1999; Prockter i Pappalardo, 2000; Sotin i Tobie, 2004; Johnson, 2005). W litosferze tej występują ruchy tektoniczne, tak zwany kriowulkanizm i inne procesy geologiczne znane z litosfery ziemskiej. Formom lodowym obecnym na innych ciałach niebieskich poświęcono już tysiące artykułów naukowych, a nawet stworzono dedykowane im czasopisma, w których „nauki o Ziemi” spotyka- 
ją się w zastosowaniach ziemskich i pozaziemskich (np. czasopismo Icarus, Earth and Planetary Science Lettres). Informacje z dziedziny „nauk o Ziemi” zbierane poza jej powierzchnią nie powinny pozostać niezauważone przez badaczy powierzchni Ziemi. Tak jak stosowna jest analogia odnośnie do Ziemi w poznawaniu innych ciał niebieskich (Marchant i Head, 2007), tak samo powinna ona mieć zastosowanie w stosunku do Ziemi: analogię tę można, a niekiedy trzeba odwrócić (Dobiński, 2012).

W odniesieniu do miejsca lodu na powierzchni Ziemi można zatem przyjąć stanowisko, że podobnie jak na innych ciałach niebieskich, lód może tworzyć (lito)sferę lodową zarówno na powierzchni lądów, jak i - ze względu na niewielką gęstość - także na powierzchni oceanów. Propozycja ta jest całkowicie logiczna i spójna z osiągnięciami szeroko rozumianych nauk o Ziemi. Co więcej, nie jest ona wcale nowa. Warto w tym miejscu przytoczyć fragment artykułu A.B. Dobrowolskiego z 1953 r. oraz zwrócić uwagę na sposób argumentowania rzadko spotykany we współczesnych wypowiedziach naukowych:

„Z punktu widzenia naukowego trzeba wiedzieć, czy mamy traktować lód na równi ze zwykłymi, stałymi składnikami powierzchni Ziemi, a w szczególności - czy pokrywy lodowe mają być uważane za skały w petrograficznym znaczeniu tego wyrazu, innymi słowy, czy są one uważane za takie przez petrografów. Otóż, kwestii takich dotychczas nie stawiano, nie przychodziły po prostu do głowy (wytłuszczenie moje W.D.) Wyjątkowe bowiem własności termodynamiczne lodu wytworzyły o nim potoczne pojęcie, które nie ma innego uzasadnienia prócz pewnych przyzwyczajeń (jw. W.D.). To jednak pojęcie było w powszechnym obiegu wśród przyrodników i.geografów i sprawiło między innymi, że nie zajmowali się sprawami lodu petrografowie. Nie było nawet w zwyczaju, mówiąc o pokładach lodu, używać terminu petrograficznego 'skała'. Na lód patrzyło się wciąż jak na jakieś ciało dodatkowe, bynajmniej nie analogiczne do innych twardych składników globu ${ }^{1}$. Za linię brzegową lądów polarnych brało się powszechnie nie brzeg pokrywy lodowej, lecz brzeg 'gruntu' - widoczny czy niewidoczny. Już w roku 1914 w książce pt. 'Wyprawy polarne' autor (tj. A.B. Dobrowolski - W.D.) sformułował poglądy wręcz przeciwne ${ }^{2}$. Wobec tego, że nie ogłosił ich w oddzielnej rozprawie, pozostały one geografom nieznane. W $1923 \mathrm{w}$ dziele swoim pt.

\footnotetext{
${ }^{1}$ Dobrowolski powołuje się tu na swój artykuł z 1931 r.: La glace au point de vue petrographique (Essai de classification des roches de glace), Bulletin de la Société française de minéralogie, 54, 1-2. Paris.

${ }^{2}$ Powołuje się tu na publikację: Dobrowolski A.B., 1914, Wyprawy polarne. Cz. naukowa. (Expeditions polaires), Kasa im. Mianowskiego (Instytut Mianowski), Warszawa (cyt.: „... język lodu wysuwa się w fale często daleko za brzeg i tym sposobem przysparza lądowi niemało obszaru (wszystkie wytłuszczenia - W.D.), tworząc własną, swoistą linię, która maskuje istotną falistość brzegów. Najjaskrawiej i najwspanialej ten udział lodu w tworzeniu wybrzeża występuje w owych potwornych 'barierach', co płaską równiną na całe setki kilometrów wrzynają się w zatokowe wyrwy morza Weddella i morza Rossa, zwiększając poważnie poziome wymiary lądu oraz niwelując rzeźbę konturów brzegowych".
} 
'Historia naturalna lodu' (s. I, II, 411, 412), szczegółowiej zaś w roku 1931³, autor starał się wprowadzić pojęcie petrografii lodu wraz z ogólną charakterystyką skał lodowych i pierwszą próbą ich klasyfikacji. Przed wojną próby te wywołały żywszy oddźwięk pro i contra tylko wśród kolegów radzieckich ${ }^{4}$ (s. 17-21). Obecnie jednak petrografowie zaczynają już na serio wchodzić na pole badań lodowych ${ }^{5}$ (s. 448, 449) i nie wahają się pokładów lodowych nie tylko nazywać skałami, ale i badać jak zwyczajne skały. Pojęcie potoczne linii brzegowej lądów polarnych winno więc ulec zmianie".

We wzmiankowanej pracy (Dobrowolski, 1951) autor podaje, że British Glaciological Society podejmował na lodowcu Jungfrau-Joch systematyczne badania petrograficzne, których wyniki publikowane były także w Journal of Glaciology. Współcześnie zrozumienie tego zagadnienia nie wydaje się lepsze.

Narodziny koncepcji lodowej litosfery można zatem datować na rok 1914. Któż by pomyślał, że w badaniach glacjologicznych na świecie powróci ona w XXI w. w postaci badań występowania lodu na innych ciałach niebieskich. Współcześnie, nie znając jeszcze cytowanych tu prac A.B. Dobrowolskiego z 1951 i 1953 r. sformułowano podobną opinię w szerszym już kontekście następująco: „Poprawne sklasyfikowanie roli lodu w trzech podstawowych sferach Ziemi oparte na jego stanie skupienia oraz włączenie lodowców i lądolodów w zakres litosfery nie powinno być trudne, jeżeli jako naukowcy nie ograniczymy się jedynie do naszej planety przyjmując taką klasyfikację. Główną przeszkodą, z powodu której różne typy lodu na Ziemi nie są powszechnie klasyfikowane jako rodzaj skały nie jest naukowy dowód, lecz siła przyzwyczajenia i bezkrytycznej tradycji” (Dobiński, 2006, s. 238).

\section{Wnioski}

W istocie to klasyfikacja lodu ma decydujące znaczenie w określeniu granic Antarktydy. Prawidłowa, poprawna klasyfikacja jest jednym z najważniejszych, porządkujących wiedzę naukową zadań badawczych. Nie jest to zadanie łatwe i zależy od przyjętych kryteriów i definicji oraz natury środowiska. Oparta na dowodzie wiedza, a wraz z nią definicja jest ostatecznym rezultatem naukowego poznania. Dzięki niej można właściwie klasyfikować zdobytą wiedzę oraz ją systematyzować.

Bez zmiany klasyfikacji lodu i przeniesienia go z hydrosfery, która powinna pozostać ograniczona do wody w postaci cieczy, do litosfery, w której jest miejsce dla wszystkich ciał stałych występujących na Ziemi, nie jest możliwe pozostawienie Antarktydy w zbiorze kontynentów. Nie jest też możliwe jednoznaczne określenie zarówno jej granic, jak i powierzchni.

\footnotetext{
${ }^{3}$ Autor powołuje się tu na: Dobrowolski (1931).

${ }^{4}$ Autor powołuje się na publikację: Kalesnik S.V., 1939, Obščaja glaciologija, Leningrad.

${ }^{5}$ Autor powołuje się na opracowanie: Dobrowolski (1951).
} 
Taka klasyfikacja daje także pełne podstawy do wliczenia lodowców szelfowych jako części kontynentu Antarktydy, a także naukowe uzasadnienie terminu „góra lodowa” który można traktować dosłownie, ponieważ - tak jak pumeks - jest fragmentem litosfery.

W świetle powyższych ustaleń, a szczególnie dzięki odkryciom naukowym ukazującym miejsce lodu na powierzchni innych ciał niebieskich Układu Słonecznego oraz aby zachować jedność nauki, logiczną konsekwencją jest zaakceptowanie każdego rodzaju lodu morskiego jako pływającej części litosfery, tak jak się to dzieje w odniesieniu do innych planet i księżyców.

Wystąpienie z postulatem zmiany klasyfikacji lodu do międzynarodowych organizacji naukowych mogłoby przynieść prestiż polskim geografom. Postulat nie byłby zresztą nowy - jako pierwszy argumentów ku temu dostarczył A.B. Dobrowolski, a został już wyartykułowany w innej pracy autora (Dobiński, 2006).

Dziękuję bardzo trzem recenzentom, których uwagi i sugestie pomogły mi poprawić strukturę, styl i doprecyzować niektóre wypowiedzi. Praca została napisana w ramach realizacji projektu finansowanego ze środków Narodowego Centrum Nauki DEC$-2012 / 07 / \mathrm{B} / \mathrm{ST} 10 / 04268$.

\section{Piśmiennictwo}

Bański J., 2010, Granica w badaniach geograficznych - definicja i próby klasyfikacji, Przegląd Geograficzny, 82, 4, s. 489-508.

Bockheim J.G., 1997, Properties and classification of Cold Desert Soils from Antarctica, Soil Science Society of America, Journal, 61, s. 224-231.

Bockheim J.G., Hall, K.J., 2002, Permafrost, active-layer dynamics and periglacial environments of continental Antarctica, South African Journal of Science, 98, s. 82-90.

Bolewski A., Manecki A., 1993, Mineralogia szczegótowa, Polska Agencja Ekologiczna, Wydawnictwo PAE, Warszawa.

Bryan S.E., Cook A., Evans J.P., Colls P.W., Wells M.G., Lawrence M.G., Jell J.S., Greig A., Leslie R., 2004, Pumice rafting and faunal dispersion during 2001-2002 in the Southwest Pacific: record of a dacitic submarine explosive eruption from Tonga, Earth and Planetary Science Letters, 227, s. 135-154; doi: 10.1016/j.epsl.2004.08.009

Campbell I.B., Claridge G.G.C., 2009, Antarctic permafrost soils, [w:] R. Margesin (red.), Permafrost Soils, Soil Biology, 16, Springer-Verlag, Berlin Heidelberg, s. 17-31.

Convey P., Bindschadler R., Di Prisco G., Fahrbach E., Gutt J., Hodgson D.A., Mayewski P.A., Summerhayes C.P., Turner J., \& the ACCE Consortium, 2009, Antarctic climate change and the environment, Antarctic Science, 21 (6), s. 541-563; doi: http://dx.doi. org/10.1017/S0954102009990642

Dobrowolski A.B., 1931, La glace au point de vue petrographique (Essai de classification des roches de glace), Bulletin de la Société Française de Minéralogie, 54, 1-2 (5-19), Paris.

Dobrowolski A.B., 1951, O pewnym zagadnieniu z petrografii lodu, Acta Geologica Polonica, 2, 4, s. 447-451. 
Dobrowolski A. B. 1953, Petrografia lodu a pojęcie linii brzegowej lodu polarnego, Acta Geologica Polonica, 3, 1, 190-192.

Dobiński W., 2006, Ice and environment: A terminological discussion, Earth-Science Reviews, 79, 229-240.

Dobiński W., 2011, Permafrost, Earth-Science Reviews, 108, s. 158-169.

Dobiński W., 2012, The Cryosphere and Glacial Permafrost as its Integral Component, Central European Journal of Geosciences, 4, 4, s. 623-640.

Everdingen van R.O., 1998, Multi-Language Glossary of Permafrost and Related Ground-Ice Terms. Definitions, University Printing Services, University of Calgary, Calgary.

Forget F., Haberle R.M., Montmessin F., Levrard B., Head J.W., 2006, Formation of glaciers on Mars by atmospheric precipitation at high obliquity, Science, 311, s. 368-371; doi: 10.1126/science.1120335.

French H.M., 2007, The Periglacial Environment, 3rd edition, Wiley, Chichester, UK.

Fretwell P., Pritchard H.D., Vaughan D.G., Bamber J. L,. Barrand N.E., Bell R., Bianchi C., Bingham R.G., Blankenship D. D., Casassa G., Catania G., Callens D., Conway H., Cook A. J., Corr H.F.J., Damaske D., Damm V., Ferraccioli F., Forsberg R., Fujita S., Gim Y., Gogineni P., Griggs J.A., Hindmarsh R.C.A., Holmlund P., Holt J. W., Jacobel R.W., Jenkins A., Jokat W., Jordan T., King E.C., Kohler J., Krabill W., Riger-Kusk M., Langley K.A., Leitchenkov G., Leuschen C., Luyendyk B.P., Matsuoka K., Mouginot J., Nitsche F.O., Nogi Y., Nost O.A., Popov S.V., Rignot E., Rippin D.M., Rivera A., Roberts J., Ross N., Siegert M.J., Smith A.M., Steinhage D., Studinger M., Sun B., Tinto B.K., Welch B.C., Wilson D., Young D.A., Xiangbin C., Zirizzotti A., 2013, Bedmap2: improved ice bed, surface and thickness datasets for Antarctica, The Cryosphere, 7, s. 375-393; doi: 10.5194/tc-7-375-2013.

Gugielmin M., 2012, Advances in permafrost and periglacial research in Antarctica: A review, Geomorphology, 155-156, s. 1-6; doi: 10.1016/j.geomorph.2011.12.008

Hall D.,Wood M.K., 1985, A molecular-packing analysis of the crystal structures of ice, Acta Crystalographica, B41, s. 169-172.

Head J.W., Neukum G., Jaumann R., Hiesinger H., Hauber E., Carr M., Masson P., Foing B., Hoffmann H., Kreslavsky M., Werner S., Milkovich S., van Gasselt S., and the HRSC Co-Investigator Team, 2005, Tropical to midlatitude snow and ice accumulation, flow and glaciation on Mars, Nature, 434, s. 346-351, doi: 10.1038/nature03359.

Johnson T.V., 2005, Geology of the icy satellites, Space Science Reviews, 116, s. 401-420.

Marchant D.R., Head J.W., 2007, Antarctic dry valleys: Microclimate zonation, variable geomorphic processes, and implications for assessing climate change on Mars, Icarus, 192, s. 187-222, doi: 10.1016/j.icarus.2007.06.018.

Mc Kinnon W., 1999, Convective instability in Europa's icy shell, Geophysical Research Letters, 26, 7, s. 951-954.

Prockter L.M., Pappalardo R.T., 2000, Folds on Europa: Implications for crustal cycling and accommodation of extension, Science, 289, s. 941-943.

Shumskii P.A., 1964, Principles of Structural Glaciology. The Petrography of Fresh-water Ice as a Method of Glaciological Investigation (translated by D. Kraus), Dover Publications, New York.

Solomatin V.I., Belova N.G., 2008, Systematization of underground ice, [w:] D.L. Kane, K.M. Hinkel (red.), Proceedings of the Ninth International Conference on Permafrost. University of Alaska Fairbanks, June 29-July 3, 2008, Institute of Northern Engineering University of Alaska Fairbanks, Fairbanks, s. 1671-1673.

Sotin C., Tobie G., 2004, Internal structure and dynamics of the large icy satellites, C.R. Physique, 5, s. 769-780. 
Summerhayes C., 2009, Chapter 1. The antarctic environment in the global system, [w:] J. Turner, R. Bindschadler, P. Convey, G. Di Prisco, E. Fahrbach, J. Gutt, D. Hodgson, P. Mayewski, C. Summerhayes (red.), Antarctic Climate Change and the Environment, Scientific Committee on Antarctic Research, Scott Polar Research Institute, Victoire Press, Cambridge, s. 1-32.

Washburn A.L., 1973, Periglacial Processes and Environments, Edward Arnold, London.

[Wpłynęło: grudzień 2015; poprawiono: kwiecień 2016 r.]

\section{WOJCIECH DOBIŃSKI}

\section{ICE CLASSIFICATION AS A BASIS FOR DETERMINING THE BORDERS AND AREA OF ANTARCTICA}

Antarctica is commonly perceived to be a continent, and so must first and foremost have a clearly defined area and borders, if it is to be called a land. The area of each such land is determined by its borders. The question of the border between land and sea has everywhere raised certain doubts, but nowhere are these as severe as in the case of the Antarctic. Being entirely covered with ice creeping down to the ocean, Antarctica has a boundary that takes the form of an ice barrier along $95 \%$ of its length, with the ice in question entering the sea to a greater or lesser extent. There is thus no unified position as to where the borders of Antarctica should be taken to lie. Rather three different positions maintain that:

1. the border is the limit of the Antarctic ice sheet bedrock protruding above the water surface - and hence an entity particularly hard to determine given the aforementioned high level of coverage by a continental glacier;

2. the boundary of the Antarctic continent can be defined as a "grounding line", i.e. a line where the creeping ice sheet as a whole rests on the sea-bed, and is thus in no part supported by water, i.e. floating.

3. the boundary of the continent is a land border together with the ice-barrier of glaciers ending in the sea, in particular ice shelves (the Antarctic continent is also sometimes taken to include so called "fast ice", i.e. long-term sea ice frozen to the land or ice shelves and thus remaining at a standstill).

Depending on criterion for the border that is adopted, Antarctica's area can be seen to change markedly (in comparison with other continents). The size is usually calculated at between 13.5 and $14 \times 10^{6} \mathrm{~km}^{2}$.

However, this is not the end of the problems with defining borders and area in the case of Antarctica. As a continent may be deemed a continuous (in Latin continuus) land, hence the name of continent, it forms part of the lithosphere. However, ice joins other forms of water in being classified as part of the hydrosphere, and this precludes it being recognised as a component of the lithosphere. Antarctica is therefore believed commonly to be called a continent in a manner that has no regard to glaciation. In recent years, an image of the Antarctic bedrock called Bedmap 2 has been prepared on the basis of georadar research. This shows that $5.5 \times 10^{6} \mathrm{~km}^{2}$ of Antarctic bedrock, or $44.7 \%$ of the entire area, is located below sea level. This means that only about half 
of the surface of the continent in the traditional sense can actually be recognised as land, or rather an archipelago similar to the one located in the Canadian Arctic. In nevertheless remains common for ice to be treated as a mineral and as rock in geology. On this basis, its return to the lithosphere has long been postulated, while the lack of such a change in reality has tended to cause considerable disruption in science, to the extent that even an unambiguous determination of whether Antarctica is a continent is not permitted. The concept of the ice-lithosphere is not unknown to science, given that it is commonly present on other celestial bodies of the Solar System. There is no requirement that analogies relating to knowledge in the Earth sciences should be one-way only, with the effect that the analogy based on the principle of uniformitarianism can and should be reversed: it is not the Earth, as something exceptional in space, that should be the point of reference in the understanding of the cosmos, but rather the other planets that should serve as such a reference as the Earth is explored. 
http://rcin.org.pl 